Jeremiah Mutie ${ }^{1}$

\title{
Care for the Sick in Early Christianity: Lessons for the Current Covid-19 Stricken Church
}

\section{Introduction}

To say that the current pandemic has affected everyone around the globe is an understatement. The pandemic that resulted in the current scenario where there are partial or total lockdowns, economic disruptions, political acrimonies as well as religious differences on how to respond to the pandemic, is believed to have started the Chinese province of Wuhan sometime in late 2019. At that point, a newer version of the severe acute respiratory syndrome coronavirus 2 (SARS-CoV-2), the pathogen that causes Covid-19, emerged in that locale. While it was later identified as the latest version of the SARS group of viruses, what made this particular disease more challenging than some other recent ones is the unavailability of either vaccines or cures at that moment. Due to the lack of effective vaccines and therapeutics at the time of its emergence, the World Health Organization was forced to declare Covid-19 a global pandemic on March 11, 2020. At that point, there were only 118,000 known cases worldwide, with the disease having spread into 114 countries and claimed the lives of 4,291 people. Of course, these numbers were to grow exponentially in all of these three categories with successive surges in Europe, the United States and Central, and South America.

One of the most fascinating exercises has been to observe how Christians (both individuals and churches) have responded to this ongoing

1 Dr Jeremiah Mutie, Professor of Theology and Church History, Southern California Seminary, California, USA; e-mail: jeremiah.mutie@socalsem.edu; ORCID: 0000-0002-9214-4671. 
pandemic. Christian involvement has been mostly in the form of attitudes towards and reaction to the policies enacted by both health and political policy makers ${ }^{2}$. However, in spite of these peculiarities that are associated with Covid-19, Christians are aware that this is not the first time they have been faced with a plague. This paper will argue that there are significant lessons that the modern Covid-19 stricken church can learn from the early church on how to care for the sick and the dead, as well as how to respond to health and government policies pertaining to the containment of the disease. Specifically, it will argue that, since the plague of Cyprian (A.D. 250-270) to the fifth century, the church responded in ways that showed affinity with contemporary Graeco-Roman medicinal advancements as well as distinctive Christian approaches to suffering in general and sickness in particular.

One delimitation is in order here, however. As students of early Christian communities know, believers, like the rest, faced many other challenges in addition to plagues. For example, in Cappadocia, there was the infamous Cappadocian famine of A.D 368. According to Susan R. Holman, the three well-known Cappadocian bishops (i.e., Basil of Caesarea, his brother Gregory of Nyssa and their friend, Gregory of Nazianzus), produced a series of "closely related sermons on the poor"3. While this and other social challenges would also be great lessons for the church today, this paper will specifically focus on challenges that are of health and medicinal nature. This delimitation is based on the understanding that these latter challenges are more comparable to the current situation than the former.

\section{Attitudes Toward and Care for the Sick in Earliest Christianity}

Right from her inception, the church has understood suffering to be part of believers' lives here on earth as they await bodily resurrection and glorification. However, as Darrel Amundsen and Gary Ferngren correctly observe, "[I]n contrast to various strains of Greek thought, which disparaged the body, regarding it as the prison of the soul, the New Testament viewed the human body as God's creation, which would one day experience redemption and

2 For a summary of Christian approaches, see G.B. Ferngren, Medicine and Health Care in Early Christianity, Baltimore 2009, p. 1-12.

3 S.R. Holman, The Hungry are Dying: Beggars and Bishops in Roman Cappadocia, Oxford Studies in Historical Theology, Oxford 2001, p. vi. 
resurrection"4. For example, in Orphic Platonism the dictum “ " $\sigma \omega ́ \mu \alpha \sigma \tilde{\eta} \mu \breve{\alpha}$ that is, "the body is the tomb", was affirmed. Indeed, in the New Testament, physical ailments were understood to serve several positive roles in the life of a Christian. Again, Amundsen and Ferngren, summarize;

Suffering itself was seen by several New Testament writers as part of God's training, by which Christians would grow toward spiritual maturity (Heb. 12:7-11; 1Pet. 4:12). They viewed affliction as being designed by God to weaken the ties of the Christian to the ephemeral lures of this world (see Jn. 17:14-16; Col. 3:2; 1Pet. 1:24-25). New Testament writers saw suffering as purposive: it corrected specific sins or weaknesses, increased self-knowledge, stimulated Christian graces (such as humility, patience, and faith), and increased dependence upon Christ (Rom. 5:2-5; Jms. 5:10-11; 1Pet. 1:6-7). These beneficial effects were possible only if faith and trust in Christ transformed suffering into a positive element. An illustration of this attitude was provided by Paul's response to his "thorn in the flesh", which appears to have been a chronic illness or disability ${ }^{6}$.

These attitudes toward physical suffering continue throughout early Christianity. They played out in these two areas: the care for the sick and the dying and Christians' relationship with secular medicine in their dealing with sickness and other forms of suffering.

Students of early Christianity agree that the literature is "full of admonitions to care for the sick"7. Examples include (but are not limited to) Hippolytus' Apostolic Tradition (especially Canon 20 - and the follow-up document known as the Canons of Hippolytus), Polycarp's Epistle to the Philippians 6, Pseudo-Clement's De Virginitate, Tertullian's Ad Uxorem 2, 4, Justin's Apology 1, 67, and Jerome's Epistle 52, 15-16 ${ }^{8}$. Only the Hippolytan works will be briefly highlighted here.

Hippolytus' work entitled Apostolic Tradition is part of a larger corpus of some early church writings known as "church orders". These were works

4 D.W. Amundse - G.F. Ferngren, The Early Christian Tradition, in: Caring and Curing: Health and Medicine in the Western Religious Traditions, ed. R.L. Numbers D.W. Amundsen, New York 1986, p. 46.

J. Mutie, Death in Second-Century Christian Thought: The Meaning of Death in Earliest Christianity, Eugene 2015, p. 40.

Amundse - Ferngren, The Early Christian Tradition, p. 44.

Amundse - Ferngren, The Early Christian Tradition, p. 48.

8 Amundse - Ferngren, The Early Christian Tradition, p. 60, n 5. 
that "were systematic manuals of disciplinary and liturgical for which the collective authority of the whole apostolate was claimed". They included such works as the Didache, the Apostolic Tradition, the Didascalia, the Apostolic Church Order, the Apostolic Constitutions, among others ${ }^{10}$. The focus here is on the Apostolic Tradition.

While there are significant debates concerning the identity of Hippolytus of Rome, whose seated statue "adorns the entrance to the famous Vatican Library, the Bibliotheca Apostolica Vaticana" "11, there is no doubt that the document attributed to him, the Apostolic Tradition, has been impactful. Concerning his influence on the Roman Catholic Church, Markus explains that,

On 25 January 1959, John XXIII had called an ecumenical council to gather at Rome ('Vatican II') and the order to place this statue of Hippolytus at the grand staircase to the Vatican Library was a marker for an entire ecclesio-political programme, connected with the forthcoming council: not Peter, who was seen as the first bishop of Rome, and whose see John XXIII had inherited, but 'the most learned church man' Hippolytus became the reference point at the entrance to the archives of the Church to welcome visitors and readers of the books and manuscripts of the Vatican ${ }^{12}$.

9 Hippolytus, Traditio Apostolica, tr. B.S. Easton, New York 1934, p. 1.

10 The others are the Epitome, the Testament of Our Lord, the Canons of Hippolytus and Sarapion's Prayers.

11 M. Vinzent, Writing the History of Early Christianity: From Reception to Retrospection, Cambridge 2019, p. 162.

12 Vinzent, Writing the History of Early Christianity, p. 163. Vinzent further explains that "Indeed, John XXIII's plan was fulfilled, as we can see from the documents of Vatican II and their many reflections of the Apostolic Tradition, this early Christian text that comprises catechetical and liturgical material and has been associated with the name Hippolytus since the fifth century at the latest, a book that is mentioned by the title on the plinth of the statue (A]ПО $\Sigma$ TO $\Lambda$ IKH ПАР $\triangle \mathrm{O} \Sigma \mathrm{I} \Sigma$ " (Vinzent, Writing the History of Early Christianity, p. 163). For a recent treatment of the question of the reconstruction of Hippolytus' Apostolic Tradition, see J.F. Baldovin, Hippolytus and the Apostolic Tradition: Recent Research and Commentary, "Theological Studies" 64 (2003) p. 520-542. Casting doubt on the authorship of the document by Hippolytus of Rome, Baldovin concludes: "Even if we could be sure that Hippolytus was Roman, there were 16 commemorations of martyrs named Hippolytus listed in the fifth-century Martyrologium Hieronymianum. Where then does our prolific writer the antipope Hippolytus come from? Cerrato has argued more recently and convincingly that the biblical commentaries attributed to Hippolytus are of Eastern origin" (Vinzent, Writing the History of Early Christianity, p. 523). 
One of the key liturgical and catechetical material is the Apostolic Tradition. According to Brent, this is "a work of the Roman Hippolytan school (since it is found on the statue's list), a work eventually assigned to Hippolytus in the church order literature like the Epitome of Book VIII of the Apostolic Constitutions, much in the same manner as another famous Roman author, Clement, became a cipher for 'the convergence of Jewish and Gentile Christianity" "13. It addresses the question of caring for the sick. It does this mostly in Canon $20^{14}$.

A brief comment on the care for the sick comes in the midst of the writer's discussion of the requirements for baptism for catechumens in Canon 20. Among other requirements (such as having lived soberly, honored widows, etc.), the author mentions that they were required to "have visited the sick"15. While there is no elaboration of this specific requirement, it clearly, is part of a larger set of virtues that were understood to be indicators of spiritual maturity of the new believer. The inquiry as to whether the catechumen fulfilled this and other specific requirements, was done after a three-year period of

13 A. Brent, Hippolytus and the Roman Church in the Third Century: Communities in Tension before the Emergence of a Monarchical Bishop, Supplements to Vigiliae Christianae 31, Leiden 1995, p. 397, quoted in Baldovin, Hippolytus and the Apostolic Tradition, 526. For more critical discussion on the authorship of the Apostolic Tradition, see P.F. Bradshaw - M.E. Johnson - L.E. Phillips, The Apostolic Tradition: A Commentary, Minneapolis 2002; A. Stewart-Sykes, On the Apostolic Tradition: An English Version with Introduction and Commentary, Crestwood 2001; Tauffragen and Bekenntnis: Studien Zur Sogenannten 'Traditio Apostolica' Zu Den 'Interrogationes De Fide' and Zum 'Romischen Glaubensbekenntnis', ed. W. Kinzig - C. Markschies - M. Vinzent, Arbeiten Zur Kirchengeschichte 74, Berlin 1999; P. Bradshaw, Redating the Apostolic Tradition: Some Preliminary Steps, in: Rule of Prayer, Rule of Faith: Essays in Honour of Aidan Kavanagh, O.S.B, ed. A. Kavanagh - N. Mitchell - J.F. Baldovin, Collegeville 1996.

14 For this work, I am using Easton's translation. Concerning its manuscript preservation, Easton concludes: "The original Greek of the Apostolic Tradition has not been recovered, except in small fragments. The Latin is generally trustworthy, but is incomplete. The only other primary version, the Sahidic, is likewise incomplete, and the results of the moderate abilities of its translator have been further confused in later transmission. The Arabic is a secondary text, offering little that the Sahidic does not contain. The only practically complete version, the Ethiopic, is tertiary and is otherwise unreliable. All four of these versions presuppose a common Greek original, in which two different endings have been conflated. The other sources, the Constitutions, the Testament, and the Canons, are frank revisions, in which the original is often edited out of recognition or even flatly contradicted. Under these conditions the restoration of a really accurate text is manifestly impossible" (Hippolytus, Traditio Apostolica, tr. Easton, p. 31).

15 Hippolytus, Traditio Apostolica, tr. Easton, p. 44. 
catechetical instruction after conversion. As Thomas Finn explains, "[At] the end of the three years stood a second inquiry, this time into the catechumen's way of life, seeking to what extent the catechumenate thus far had been effective for conversion. Did the catechumen actually honor the widows? truly visit the sick? really do "every kind of good work?"'16. Thus, not only did the care for the sick indicate one's spiritual maturity and act as part of the qualifications for baptism, but it was part of the requirements that made it possible for one to become part of the electi, the group that would now undergo several weeks of exorcisms leading up to his baptism.

Hippolytan scholars see the theme of the care for the sick, that is briefly introduced in the Apostolic Tradition as being fully explored in the later document known as the Canons of Hippolytus. A fourth century document of Egyptian provenance and patterned after the Sacramentary of Sarapion (or Prayers of Sarapion), the Canons of Hippolytus is a church order which is "a reworking of the document known as the Apostolic Tradition"17. However, the exact relationship between the two documents continues to be debated within academic circles since there are significant questions concerning the authorship of the Apostolic Tradition itself. What is clear, however, is that there are key additions to the Apostolic Tradition in the Canons. As Barret-Lennard explains concerning the added material, "some of these additions and modifications concern the ministry to the sick" ${ }^{18}$. At least three of the canons in this document deal explicitly with matters of illness and healing. Specifically, "Canon 8 (concerning those exercising a gift of healing) Canon 24, (concerning the visiting of the sick by the bishop and the appropriate sleeping place of the sick); and Canon 25 (a regulation that deals both with the appointment of a steward of the sick by the bishop and with times of prayer)"19, are of interest here.

16 T.M. Finn, Ritual Process and the Survival of Early Christianity: A Study of the Apostolic Tradition of Hippolytus, "Journal of Ritual Studies" 3/1 (1989) p. 74.

17 R. Barrett-Lennard, The Canons of Hippolytus and Christian Concern with Illness, Health, and Healing, "Journal of Early Christian Studies" 13/2 (2005) p. 138. Barret-Lennard further explains that "The Canons of Hippolytus, originally written in Greek but extant only in an Arabic translation of a lost Coptic version, is a collection of thirty-eight canons and represents an adaptation of the Apostolic Tradition, which appears in variant forms in many liturgical documents of the period" (Barrett-Lennard, The Canons of Hippolytus and Christian Concern with Illness, Health, and Healing, p. 139).

18 Barrett-Lennard, The Canons of Hippolytus and Christian Concern with Illness, Health, and Healing, p. 140-141.

19 Barrett-Lennard, The Canons of Hippolytus and Christian Concern with Illness, Health, and Healing, p. 141. 
Just as in the Apostolic Tradition, "catechumens at the time of baptismal preparation are asked (or, more correctly, their sponsors are asked) whether the candidates have kept the commandments, visited the sick, and given to the needy" ${ }^{20}$. In Canon 9 specifically, responsibility for caring for the sick is seen to be of the same level as caring for widows. Here, care for the sick was seen as a communal affair, involving everyone in the body of believers. As elucidated in Canon 20 of the Apostolic Tradition, this would be a valid reason for not undertaking Wednesday or Friday fast. However, there are further stipulations concerning those with the gift of healing as well as bishops and other leaders of the church.

Already in the Apostolic Tradition, there were indications of people who had been given the gift of healing. Particularly, focusing on the requirements for ordination, the document explains in Canon 14, 5 that " $[\delta \varepsilon]$ If anyone says, 'I have received the gift of healing', hands shall not be laid upon him: the deed shall make manifest if he speaks the truth" ${ }^{21}$. A parallel requirement is evident in Canon 8 of the Canons of Hippolytus, which states that "If someone asks for his ordination saying, 'I have received the gift of healing', he is to be ordained only when the thing is manifest and if the healing done by him comes from God"22. While the specifics of this requirement, which is first stipulated in the Apostolic Tradition and then, with free modifications, adopted in the Canons, are unclear, it is clear that this was a gift present in the non-ordained members of the church. That is why, for those who made a request for ordination, the authenticity of their claim to this gift had to be tested and established first. In any case, it is very clear that concern and care for the sick was amongst the highest requirements for an ordained leadership position.

The final aspect pertains to the ministry to the sick by the bishops and other leaders of the church. There are several regulations that are put forward in the Canons on the role of the church leaders in the care of the sick. As Barrett-Lennard explains, "[I]n the ordination prayer for the bishop in Canon 3 , there is a strong statement, unparalleled in the Apostolic Tradition, that concerns the bishop's role in ministering to the sick"23. The prayer, which

20 Barrett-Lennard, The Canons of Hippolytus and Christian Concern with Illness, Health, and Healing, p. 144.

21 Hippolytus, Traditio Apostolica 41.

22 The Canons of Hippolytus, ed. P. Bradshaw, Liturgical Studies 2, Nottingham 1987, p. 16, quoted in Barrett-Lennard, The Canons of Hippolytus and Christian Concern with Illness, Health, and Healing, p. 139.

23 Barrett-Lennard, The Canons of Hippolytus and Christian Concern with Illness, Health, and Healing, p. 150. 
is to be made at the bishop's consecration, asks God to "Give him power to loosen every bond of the oppression of demons, to cure the sick and crush Satan under his feet quickly" 24 . This was the standard prayer for consecration of bishops in Egypt in the $4^{\text {th }}$ century C.E. Thus, according to this canon, while, at the consecration, "a bishop may not necessarily be someone who already had a recognized gift of healing, but this petition in his consecration prayer suggests that curing the sick was one of the roles associated with the episcopal and presbyteral orders" 25 . The requirement that the same prayer be offered during the consecration of a presbyter is spelled out in Canon 4.

Finally, when it comes to the actual ministry of caring for the sick, as far as the bishops are concerned, this is spelled out in Canon 24. Clearly an expansion of Canon 34 of the Apostolic Tradition, this canon, providing directions on how church leaders should go about caring for the sick in their homes, stipulates:

A deacon shall accompany the bishop at all times to inform him of everyone's condition. He is to inform him about each sick person, because it is important for the sick person that the high-priest visits him. He is relieved of his sickness when the bishop goes to him, especially when he prays over him, because the shadow of Peter healed the sick, unless his lifespan is over. The sick are not to sleep in the dormitory, but rather the poor. That is why he who has a home, if he is sick, is not to be moved to the house of God. Rather he is only to pray and then return home ${ }^{26}$.

Thus, on the one hand, the Apostolic Tradition "is primarily concerned with the general role of the deacons and subdeacons in waiting on the bishop, and it merely notes the particular task of reporting to the bishop the

24 Hippolytus, Traditio Apostolica, Canon 3, quoted in B. McNary-Zak et al., Useful Servanthood: A Study of Spiritual Formation in the Writings of Abba Ammonas, Cistercian Studies, Trappist 2010, p. 91-92.

25 Barrett-Lennard, The Canons of Hippolytus and Christian Concern with Illness, Health, and Healing, p. 150.

26 Hippolytus, Canones Hippolyti, Canon 24, quoted in Barrett-Lennard, The Canons of Hippolytus and Christian Concern with Illness, Health, and Healing, p. 151. See also chapter 34, which reads: "Let each deacon, with the subdeacon, attend on the bishop. Let it also be told to him who are sick, so that, if it is pleasing to the bishop, he may visit them. For a sick person is greatly consoled when the high priest remembers him" (Barrett-Lennard, The Canons of Hippolytus and Christian Concern with Illness, Health, and Healing, p. 151). 
names of any who are ill"27. On the other hand, the Canons' concern is on the ministry of the bishops towards the sick in the body of Christ.

Here is a good place to transition to the attitudes and approaches towards medicinal therapeutics in the early church. While it is clear that the bishop's prayer was believed to have some therapeutic power (especially with the use of the phrase "prays over him"), it is clear that there was a recognition of the limit of this healing power. Indeed, "[T] he author of the Canons includes an 'exception clause' to allow for the possibility of a person not experiencing a restoration of health when their "lifespan is over" 28 . Death as "healing" was sometimes considered as an "eschatological healing" ${ }^{29}$. One wonders, however, if this "prayer for healing", accompanied by the ritual of the laying of hands, left any place for natural therapeutics ${ }^{30}$.

\section{Attitudes Towards Natural Therapeutics in the Early Church}

After the brief discussion of the care for the sick in the early church, attention now shifts to the attitudes that believers had towards natural therapeutics for diseases. Other related matters like the question of organized care as well as charitable activity towards the sick, also come into focus here. Some have contended that, concerning the care for the sick, just like other issues in early Christianity, there seems to be a difference between the approach before and after the legalization of Christianity in A.D. 313. Thus, it is argued that "[A] after the legalization of Christianity in A.D. 313 and the influx of state funds that came to be directed to its support, the creation of permanent medical institutions marked the decline of a congregation-centered approach in favor of organized institutional efforts on behalf of those requiring medical treatment" ${ }^{31}$. Is this true? What were the actual approaches from a medical viewpoint?

27 Barrett-Lennard, The Canons of Hippolytus and Christian Concern with Illness, Health, and Healing, p. 151.

28 Barrett-Lennard, The Canons of Hippolytus and Christian Concern with Illness, Health, and Healing, p. 154.

29 See the articles in Temple of the Holy Spirit: Sickness and Death of the Christian in the Liturgy: The Twenty-First Liturgical Conference Saint-Serge, tr. M.J. O'Connell, New York 1983. See also J.C. Thomas, The Devil, Disease, and Deliverance: Origins of Illness in New Testament Thought, Sheffield 1998.

30 The phrase "natural therapeutics", as used in this paper, refers to anything other than divine healing.

31 Amundse - Ferngren, The Early Christian Tradition, p. 113. 
A better approach to these questions is to investigate the specific attitudes and approaches that early Christians had towards natural therapies to diseases (as opposed to divine healing). As it has already been pointed out in the introduction, just because early Christians practiced exorcisms, prayers for the sick as well as the gift of healing, it is sometimes (wrongly) assumed that the early church despised natural therapeutics. This is especially so, given the near consensus understanding that, right from her inception, Christianity was concerned with physical healing. This point was highlighted by Adolf Harnack, who commented that "Jesus appeared among his people as a physician. 'The healthy need not a physician, but the sick' (Mark 2:17, Luke 5:31)"32. He further adds:

Jesus says very little about sickness; he cures it. He does not explain that sickness is health; he calls it by its proper name, and is sorry for the sick person. There is nothing sentimental or subtle about Jesus; he draws no fine distinctions, he utters no sophistries about healthy people being really sick and sick people really healthy. He sees himself surrounded by crowds of sick folk; he attracts them, and his one impulse is to help them. Jesus does not distinguish rigidly between sicknesses of the body and of the soul; he takes them both as different expressions of the one supreme ailment in humanity ${ }^{33}$.

How did the church continue this tradition, if we may ask?

Following the lead of its founder, Christianity, from her early days, "assumed the form of 'the religion of salvation or healing', or of 'the medicine of soul and body', and at the same time it recognized that one of its cardinal duties was to care assiduously for the sick in the body" ${ }^{\prime 4}$. After

32 A. Harnack, The Mission and Expansion of Christianity in the First Three Centuries, v. 1, tr. J. Moffat, New York 1905, p. 70.

33 Harnack, The Mission and Expansion of Christianity in the First Three Centuries, v. 1, p. 70. S.J. Case further argues that "In the ancient world it was almost universally believed that the function of religion was to heal disease, and it was in just this world that Christianity took its rise. It need not be surprise us, therefore, to find that Christianity is from the start a healing religion. This fact appears in the earliest of the New Testament documents. Paul reminds the Corinthians that the officials in the church the gradation is apostles, prophets, teachers, while functions in order of importance are miracles, gifts of healings, helpers, governments, and various kinds of tongues (1 Cor. 12:28). Thus miracles and gifts of healings are first in order" (S.J. Case, The Art of Healing in Early Christian Times, "The Journal of Religion" 3/1 (1923) p. 253).

34 Harnack, The Mission and Expansion of Christianity in the First Three Centuries, v. 1, p. 74 . 
Jesus' ascension to heaven, the early church seems to have continued this healing tradition both by the means already noted (prayers and the gift of healing), but, also, through the adaptation and appropriation of natural (mainly Greek) therapeutics.

Contrary to popular opinion, evidence suggests that early Christians "employed natural means of healing, whether these means involved physicians or home or traditional remedies" ${ }^{35}$. The majority of this evidence comes not only from the practices themselves, but also from the writings of Christian thinkers throughout these early times. While all cannot be treated here, a few will suffice. These are: Tertullian, Origen, Tatian, and Arnobius. The case of Tertullian will be highlighted to illustrate these attitudes and approaches ${ }^{36}$. However, before looking at Tertullian, brief comments are in order concerning Greek medicine.

While Christianity arose from Jewish roots, it is mainly the Greeks who bequeathed natural medicine to early Christians. Greek medical roots, according to Ferngren, go back to the time of classical Greece. "[A]s early as the time of Homer", he writes, "there existed in Greek society physicians (demiourgoi) who treated wounds and set bones" ${ }^{37}$. However, this was very rudimentary, for these physicians "did not understand disease in general terms; nor were they able to frame theories that could be applied to particular cases" ${ }^{38}$. Later on, developments in medicine took place, with the idea of being healthy coming to be understood as resulting from a "harmo-

35 Amundse - Ferngren, The Early Christian Tradition, p. 13.

36 Ferngren further clarifies that there is a difference between ancient and modern nosology (classification of diseases). "The relation of a group of symptoms to a specific disease or disease agent" he writes, "is a separate recent medical concept. Greek medical authors regarded diseases not as separate entities but as groupings of symptoms that affected individuals and could be described and classified. Symptoms were indicators of changes that took place in the constitution of the individual patient. A disease represented a deviation from the normal state of a patient. Although the 'antecedent' or external cause might vary, a disease led [...] to a humoral disorder ('standing condition'), which produced a malfunction of the body. Thus a cold wind might create an excess of phlegm in the stomach, which in turn would produce indigestion" (Amundse - Ferngren, The Early Christian Tradition, p. 14-15). However, he helpfully adds that "Some diagnoses found in ancient medical literature (e.g., of tetanus, epilepsy, mumps orchitis) appear relatively clear in terms of modern nosologies. But as we learn more about rare and unusual causes of conditions, we become more cautious about making diagnoses based on the description of a few symptoms" (Amundse - Ferngren, The Early Christian Tradition, p. 15).

37 Amundse - Ferngren, The Early Christian Tradition, p. 18.

38 Amundse - Ferngren, The Early Christian Tradition, p. 18. 
nious balance of the humors of the body" 39 . These "humors", were the ones that "physicians borrowed from Empedocles (fl. 444-441 B.C.), according to which the body contained four fluids (blood, phlegm, yellow bile, and black bile), by analogy with matter, which composed of four 'elements' (earth, air, fire, and water)" ${ }^{\prime 4}$. Thus, in an attempt to restore the balance of these humors, treatment was done through "coction", which was "a mixing of the humors that usually involved the combining of dietetics with cathartic therapies (e.g., emetics, purging, or bloodletting)" ${ }^{\prime 4}$. During this time, physicians were trained through apprenticeships. While the entire issue of medical practice would be an interesting aspect of inquiry, it is the question of therapeutics (Gk. pharmaka) which is mostly of concern to us here.

The general approach to illnesses in antiquity was to emphasize prevention rather than cure. Plato, for example, provides a "recipe" for how to keep both the body and the soul healthy:

There is one protection against both: that we should not move the body without the soul or the soul without the body, and thus they will aid one another, and be healthy and well balanced. And therefore the mathematician or any one else who devotes himself to some intellectual pursuit, must allow his body to have motion also, and practise gymnastic; and he who would train the limbs of the body, should impart to them the motions of the soul, and should practise music and all philosophy, if he would be called truly fair and truly $\operatorname{good}^{42}$.

However, there was also the recognition of the fact that, even with these preventive measures, there will be times when treatment would be necessary. In this case, treatment would be a holistic approach, "that involved the use of regimen, pharmacology, and surgery" ${ }^{4}$. And, while some drugs worked,

39 Amundse - Ferngren, The Early Christian Tradition, p. 18.

40 Amundse - Ferngren, The Early Christian Tradition, p. 18. As Case further explains, in the case of Plato, "Plato views disease, not as a calamity, but as an accident. Education and a well-ordered life are the best preventives, for in this way the proper balance among the four constituent elements of the body and the three constituent parts of the soul residing in the body can be best preserved" (Case, The Art of Healing in Early Christian Times, p. 239).

41 Amundse - Ferngren, The Early Christian Tradition, p. 18.

42 Plato, Dialogo de Critica, in: Plato, The Dialogues of Plato: Selections from Charmides, Lysis, Other Dialogues and the Laws, v. 4, tr. B. Jowett, New York 1914, p. 374.

43 Amundse - Ferngren, The Early Christian Tradition, p. 20. Concerning the preventive measures, Ferngren further explains: "Preventive medicine was regarded as the 
others did not. As Hippocrates is reported to have stated in one of his famous aphorisms, "Ulcers lasting a year or longer cause the underlying bone to be eaten away and the resulting scars are depressed'. 'What drugs will not cure, the knife will; what the knife will not cure, the cautery will; what the cautery will not cure must be considered incurable" ${ }^{44}$. How did early believers approach these therapeutics, which, according to Ferngren, could "could mend broken bones, reduce dislocations, cauterize wounds, perform various kinds of surgical operations, engage in venesection or phlebotomy, administer traditional drugs and remedies, and prescribe rest and regimen that involved change of diet, exercise and baths"[? $]^{45}$.

Because of the availability especially of Greek medicine, Christians were forced to define their approach to natural therapeutics. However, contrary to some modern views, this determination was not very hard to make. This is because naturalistic medicine was "value-neutral", thus, it was considered benign in religions matters. Still, since these were naturalistic therapeutics, the need for a nuanced (we may say, distinctively Christian) approach, was necessary. "While early Christians seem for the most part to have accepted Greek medicine for the healing of disease", writes Ferngren, "one finds nuances in the manner of reception" 4 . Indeed, the process of a nuanced adaptation and modification of Greco-Roman practices extended even to the care of the Christian dead ${ }^{47}$. This approach is most prominent in the Christian apologists of the second century such as Tertullian and Justin Martyr.

Tertullian (c. 160-220/5) was a brilliant second-century defender of the faith. A lawyer by training, his thought "drew freely on biblical eschatology and on the writings of earlier Christian writers, particularly Justin

best way to maintain health. This was accomplished by means of a detailed classification of food and drink based on the properties of each, whether strong, weak, dry, moist, cool, hot, constricting, or laxative. Sleep, sexual activity, and exertion were also regulated. Treatment was adjusted to the individual, and a physician was expected to know his patients well so that he would be able to adjust their treatment in order to maintain a balance of the constituent elements of the human body" (Amundse - Ferngren, The Early Christian Tradition, p. 20).

44 Hippocrates, Hippocratic Writings, ed. G.E.R. Lloyd, New York 1978, p. 236. See also H.E. Crouch, History of Basal Cell Carcinoma and Its Treatment, "Journal of the Royal Society of Medicine" 76 (1983) 302-306.

45 Amundse - Ferngren, The Early Christian Tradition, p. 20.

46 Amundse - Ferngren, The Early Christian Tradition, p. 25.

47 For an exploration of the early church's distinctive attitude towards death and its surrounding practices, see J. Mutie, Attitudes toward Death in Greco-Roman and Early Christian Cultures, "Pakistan Journal of Historical Studies" 2/2 (2017) p. 89-115. 
and Irenaeus"48. Because of his famous passage in which he seems to disparage Greek philosophy, Tertullian has been thought of to have been ambivalent to some aspects of Greek thought including natural therapeutics. In Prescription against Heretics, Tertullian quips; "Quid ergo Athenae Hierosolymis? Quid academiae et ecclesia?" (What has Jerusalem to do with Athens, the Church with the Academy) ${ }^{49}$ Thus, due to his seeming rejection of Greek philosophy here, it is sometimes assumed that he was similarly rejected Greek medicine. But is this a correct assessment of his (and, for that matter, early Christian') views on natural therapeutics?

To fully capture Tertullian's views on Greek medicine, one must move beyond this seemingly enigmatic paragraph. Indeed, it is doubtful that Tertullian is saying what his detractors (and, sometimes, his supporters) assume he is saying. As Nicholas Wolterstoff clarifies, Tertullian's comments were part of his rhetorical argument against the deception of heretics, since, according to him, Greek philosophy was at the root of all heresies ${ }^{50}$. He writes, "Were Tertullian living in our own day, his list would be much longer: be done with Kantianized Christianity, with Hegelianized Christianity, with deconstructionist Christianity. Be done with them all. The stance of Christian toward all attempts at 'worldly wisdom' must be unrelenting opposition" "51. Rather, what Tertullian was doing here is nothing different from what Paul was doing in calling attention to the enslaving Colossian philosophy (Col 2:8). Tertullian addresses the question of Greek medicine in his other writings.

48 B.E. Daley, Hope of the Early Church: A Handbook of Patristic Eschatology, Cambridge 1991, p. 34.

49 Tertullianus, De Praescriptionibus Adversus Haereticos 7. For this work, I am using Tertullian, Ante-Nicene Fathers: Latin Christianity: Its Founder, Tertullian, v. 3, ed. P. Schaff - A. Menzies, Christian Classics Ethereal Library, Grand Rapids 1885. The full quote reads this way: "What indeed has Athens to do with Jerusalem? What concord is there between the Academy and the Church? what between heretics and Christians? Our instruction comes from 'the porch of Solomon', who had himself taught that 'the Lord should be sought in simplicity of heart'. Away with all attempts to produce a mottled Christianity of Stoic, Platonic, and dialectic composition! We want no curious disputation after possessing Christ Jesus, no inquisition after enjoying the gospel! With our faith, we desire no further belief. For this is our palmary faith, that there is nothing which we ought to believe besides" (Tertullianus, De Praescriptionibus Adversus Haereticos, ed. P. Schaff - A. Menzies , p. 505).

50 N. Wolterstorff, Tertullian's Enduring Question, in: Inquiring About God, ed. T. Cuneo, Cambridge 2010, p. 283.

51 Wolterstorff, Tertullian's Enduring Question, p. 283. 
Specifically, in his De corona chapter 8, Tertullian discusses the inventions of many things. Overall, he argues that all discoveries are sourced in God. According to him, even though Greeks invented medicine, the knowledge to invent them come from God. He writes: "Nay, if he also first strung the chord to give forth melody, I will not deny, when listening to David, that this invention has been in use with the saints, and has ministered to God. Let Æsculapius have been the first who sought and discovered cures: Esaias mentions that he ordered Hezekiah medicine when he was sick. Paul, too, knows that a little wine does the stomach good" 52 . In other words, for him, "Medicine was a gift from God" 53 . He continues the same attitude towards medicine in his Scorpiace where, while arguing for the benefits of martyrdom, Tertullian writes: "But you will admire the physician at least even in that respect, that for the most part he employs like properties in the cures to counteract the properties of the diseases, when he aids, as it were, the wrong way, succouring by means of those things to which the affliction is owing" 54 . Thus, according to him, "[P]eople foolishly flee a physician who must cut or burn, but such pain is required to produce a good end. And once a man is cured, he will praise the physician's skill'\$5. Thus, even when talking about subjects like Christian martyrdom, Tertullian freely draws from his knowledge of the medical practices of his day.

52 Tertulianus, De corona 8. I am using Ante-Nicene Fathers: Latin Christianity: Its Founder, Tertullian, v. 3, ed. P. Schaff - A. Menzies, Christian Classics Ethereal Library, Grand Rapids 1885.

53 Amundse - Ferngren, The Early Christian Tradition, p. 26. This is very important, given that Tertullian seems to be opposed to natural therapeutics in his De anima, where he "condemns physicians who are said to have practiced vivisection (ch. 10) and censures the practice of embryotomy (ch. 15)" (Amundse - Ferngren, The Early Christian Tradition, p. 26). However, as Ferngren explains, "Nowhere in the De anima [...] does he condemn physicians or medicine in universal terms. Moreover, it is clear to any reader of his works that Tertullian had studied medicine a good deal, probably as a part of his general education. He makes frequent use of medical analogies to illustrate theological and religious concepts. And he cites approvingly a number of medical writers, most prominently Soranus, who assumed an authority for Tertullian in medical matters that Galen was to have for later Christian writers" (Amundse - Ferngren, The Early Christian Tradition, p. 26). For a brief summary of the life and practice of Galen, see H.F.J. Horstmanshoff, Galen and His Patients, in: Ancient Medicine in Its Socio-Cultural Context: Papers Read at the Congress Held at Leiden University 13-15 April 1992, ed. Ph.J. van der Eijk H.F.J. Horstmanshoff - P.H. Schrijvers, Amsterdam 1995, p. 83-99.

\footnotetext{
54 Tertullianus, Scorpiace 5.

55 Amundse - Ferngren, The Early Christian Tradition, p. 27.
} 
Therefore, contrary to the view that early Christians were averse to Greek medicine, they held views towards medicine that "did not differ appreciably from those that were widely taken for granted in the Graeco-Roman world in which they lived" ${ }^{56}$. While Christians insisted on care, prayers and healing for the sick, they, nevertheless had no problem with natural therapeutics, which they argued were a gift from God. These views continued throughout the first five centuries of Christianity. This was the view of the fourth century Christian rhetorician, Arnobius of Sicca. While he will not be treated here, he regarded medicine and the medical practitioners very highly ${ }^{57}$. Again, this is very consistent with early Christians' attitudes towards other related subjects such as death ${ }^{58}$.

\section{Lessons for Today's Covid-19 Stricken Church}

Finally, the paper concludes by noting a few lessons that today's Christians, battling through the covid-19 pandemic, can learn from their earliest brothers and sisters. These lessons are drawn from two areas of concern highlighted throughout the paper. These are, first, the question of the care for the sick, and, second, the attitudes towards natural therapeutics that are being developed mainly in a fast-phased manner to combat the pandemic.

First, the early church took the care of the sick very seriously. The ability to care for the sick (including, in some cases, the gift of healing), was significant indication of spiritual maturity, being required both for baptism and church leadership. And, since medical care was more individualized than communal, the burden of the care for the sick in the church was placed on the shoulders of church orders. A key test for this was the Plague of Cyprian, a plague that spread through the Roman Empire around A.D. 250. This plague "is said to have originated in Ethiopia and to have spread rapidly through Egypt to North Africa and thence to Italy and the West as far

56 Amundse - Ferngren, The Early Christian Tradition, p. 13.

57 See Arnobius, Adversus nationes, in: The Case against the Pagans: Newly Translated and Annotated, v. 1-2, tr. G.E. McCracken, Ancient Christian Writers, Westminster 1949.

58 For early Christian care for the dead, see É. Rebillard, The Care for the Dead in Late Antiquity, v. 59, tr. E.T. Rawlings - J. Routier-Pucci, Cornell Studies in Classical Philology, Ithaca 2010. 
as Scotland, where it reached epidemic proportions" ${ }^{59}$. As Patrick Gilger explains, this plague “bears Cyprian's name neither because he was responsible for it nor because he resolved it, but because he wrote about it. It is because of his 'De Mortalitate,' a sermon written to console the faithful in the midst of the epidemic, that we know something of its effects" ${ }^{\circ 0}$. This was a lengthy epidemic, lasting between 15 and 20 years. It was a devastating epidemic according to the available records. As Ferngren explains, "[In some places the number of those who died outnumbered survivors. [For example] In Rome 5,000 people are said to have succumbed in a day" ${ }^{1}$. So, how did the church respond?

One of the most interesting observations is the contrast between the response towards the sick between pagans and Christians in antiquity, given that care for the sick was a private and not a public affair. "Without a concept of private charity", writes Ferngren, "no activity was undertaken by individuals, philanthropic organizations, or temples to ameliorate the condition of the sick, and they and their families were left for themselves, often with wholly inadequate resources" ${ }^{\prime 2}$. The main problem with the pagan cults was that they were not able to generate a community. As Rodney Stark puts it, "[S]imply put [...] pagan cults were not able to get people to do much of anything [...] And at the bottom of this weakness is the inability of nonexclusive faiths to generate belonging" ${ }^{63}$. The contrast between the pagan cults and early Christianity could not be starker!

On the other hand, Christians, guided by their conviction that "personal and corporate philanthropy [...] [is] an outworking of Christian concepts of agape and the inherent worth of individuals who bore God's image" ${ }^{4}$, responded by introducing social responsibility in dealing with the epidemic. Indeed, instead of attempting to assign blame for the pandemic, Christians saw it as an opportunity to showcase the Christian virtue of love. For example, after Cyprian, whom the pestilence is named, preached:

59 Amundse - Ferngren, The Early Christian Tradition, p. 115. This pandemic has been compared to a later one: the Justinianic plague which occurred around A.D. 540 . For more information on this plague, see P. Sarris, The Justinianic Plague: Origins and Effects, "Continuity and Change" 17/2 (2002) p. 169-182.

60 P. Gilger, Litany for a Pandemic: What a Jesuit Learned under Quarantine in Milan, "America" 222/10 (2020) p. 20.

${ }_{61}$ Amundse - Ferngren, The Early Christian Tradition, p. 116.

62 Amundse - Ferngren, The Early Christian Tradition, p. 117.

63 R. Stark, The Rise of Christianity: A Sociologist Reconsiders History, Princeton 1996. Quoted in Amundse - Ferngren, The Early Christian Tradition, p. 117.

${ }_{64}$ Amundse - Ferngren, The Early Christian Tradition, p. 117-118. 
And further, beloved brethren, what is it, what a great thing is it, how pertinent, how necessary, that pestilence and plague which seems horrible and deadly, searches out the righteousness of each one, and examines the minds of the human race, to see whether they who are in health tend the sick; whether relations affectionately love their kindred; whether masters pity their languishing servants; whether physicians do not forsake the beseeching patients; whether the fierce suppress their violence; whether the rapacious can quench the ever insatiable ardour of their raging avarice even by the fear of death; whether the haughty bend their neck; whether the wicked soften their boldness; whether, when their dear ones perish, the rich, even then bestow anything, and give, when they are to die without heirs. Even although this mortality conferred nothing else, it has done this benefit to Christians and to God's servants that we begin gladly to desire martyrdom as we learn not to fear death. These are trainings for us, not deaths: they give the mind the glory of fortitude; by contempt of death they prepare for the crown ${ }^{65}$.

It is because of such an understanding that Christians were known to be the care givers to the sick. As diseases continued to plague people in antiquity, Christians continued to be known as the ones who cared for the sick and the dying. Commenting on the later plague of 312-13, Ferngren comments that "the only care of the sick and dying during the epidemic of 312-13 was provided by Christian churches, who even hired grave diggers to bury the dead that lay in the streets" ${ }^{\prime 6}$. The list of the kinds of actions that Christians took to care for the sick, the dying and the dead, is endless. Dionysius of Alexandria, observing the kind of selfless care that presbyters, deacons and laypersons gave to the sick, commented that "most of our brethren were unsparing in their exceeding love and brotherly kindness. They held fast to each other and visited the sick fearlessly, and ministered to them continually, serving them in Christ" 67 . He adds that "they died with them most joyfully, taking the affliction of others, and drawing the sickness

65 Thascius Caecilius Cyprianus, De mortalitate. For this, I am using Cyprian, The Writings of Cyptian, Bishop of Carthage, v. 8, ed. R.E. Wallis, Ante-Nicene Fathers, Buffalo 1886. For more information on this plague, which some suggest was like today's Ebola, see K. Harper, Pandemics and Passages to Late Antiquity: Rethinking the Plague of c. 249-70 Described by Cyprian, "Journal of Roman Archeology” 28 (2015) p. 223-260.

${ }_{66}$ Amundse - Ferngren, The Early Christian Tradition, p. 118.

${ }_{67}$ Eusebius Caesariensis, Historia ecclesiastica 7, 22, 7. For this, I am using Eusebius, Ecclesiastical History, v. 14, ed. A. C. McGiffert, Nicene and Post-Nicene Fathers Second Series, Buffalo 1890. 
from their neighbors to themselves and willingly receiving their pains" ${ }^{68}$. This is in reference to the Cyprian Plague.

The lessons here for today's church are profound. While, as noted earlier, circumstances have significantly changed in that, today, the sick are mainly cared for in the hospitals and other facilities, and, that the current pandemic is contagious, the call for Christians to care for the sick and their families still remains. The onus is on the church to seek the Lord and take the advantage of any available avenues to serve the sick. The churche can hold prayers for the sick with or without their presence. She can serve the families who have the burden of caring for the sick through meeting their basic needs as well as being available to run errands for these families. The church's presence, in other words, must be noticeable. It is perhaps the only way that the world will know about the two concepts that drove the early church's care for the sick and the dead: a profound emphasis on agape love as well as a clear understanding of the doctrine of the imago Dei.

The final lesson pertains to the attitude towards natural therapeutics. At the time of the writing of this paper, there are a few authorized available cures for Covid-19 such as Veklury (remdesivir), which was approved by the US Centers for Disease Control (CDC) on October 22, 2020, and the anti-malaria malaria drug, Hydroxychloroquine. There are a number of vaccines, such as the Pfizer-BioNTech COVID-19 vaccine, the Moderna COVID-19 vaccine, and the Janssen COVID-19 vaccine, that have also been authorized for emergency use for prevention of the disease. Indeed, these have proven to be very effective in preventing Covid-19 sickness. The comparison, therefore, between early Christians' attitudes towards natural therapeutics and the current scenario, can only be made on the basis of these vaccines that are now in use.

Because of the speed and technology with which these vaccines have been developed, there has been some hesitancy to take them. Benjamin Casella captures the concerns of those who are hesitant to take the vaccines wryly, commenting:

Over the past several weeks, I have had conversations with people who have, let's say, varying points of view regarding getting the vaccine. A man who works down the street from my practice said (tongue in cheek) that the government should give the pharma companies crop dusters and warn those who don't want the vaccine to stay inside for a few minutes. On the other

68 Eusebius Caesariensis, Historia ecclesiastica 7, 22, 7. 
side of the equation, I had a conversation with a patient who told me that she would never allow anything Bill Gates had his hands on anywhere close to her body ${ }^{69}$.

Further, as Simon Montalto explains, "[T] his position is by no means exceptional, and stems from an inherent fear of something new that is relatively untried, and is compounded by misunderstanding from or confusion within the general and social media (less so in the regulated and mainstream channels), as well as unsubstantiated claims from anti-vaxxers" $" 70$. Additionally, there have been other concerns such as the suggestion that some of the vaccines were developed via a process that uses cells from aborted fetuses. Like other vaccines that have been in the market for many years, Covid-19 vaccines are believed to be safe and effective. As well, like any other natural therapeutics, of course no drug is completely safe for everyone.

Here is where Christians need to learn from their early brothers and sisters. As has been demonstrated, early believers adopted and adapted Greek natural therapeutics, believing that they were gifts from God to help them fight diseases. The same should be the attitude of current believers as they face this pandemic that, although not unprecedented, has been devastating in so many fronts. Of course, this is not to take away any realistic concerns over these vaccines. Here is where every Christian is called upon to do his/ her due research and determine which of the available vaccines are theologically and ethically desirable for him/her. But an approach to the vaccines that is in accord with how early Christians approached natural therapeutics will encourage other people who are standing in the fence to take the vaccines and get the entire world closer to getting past this truly world-stopping pandemic. Ultimately, however, as early Christians also emphasized, the truth of the matter is that death will catch up with all of us as long as the Lord tarries.

\section{Conclusion}

This paper argues that, contrary to some modern views concerning early Christians' attitudes towards sickness and therapeutics, views that see early Christians as attributing all diseases to demonic causes and rejecting

69 B.P. Casella, Covid Vaccine Helps Us Get Back to Normal, "Optometry Times" 13 (2021) p. 5.

70 S.A. Montalto, The Covid 19 Vaccine: Fear It Not!, "Malta Medical Journal" 32/3 (2020) p. 1. 
Greek medicine, in addition to prayers and the gift of healing, early believers actually adopted and utilized natural therapeutics to treat and cure diseases. As it has been demonstrated, even those early church fathers who are thought to have been opposed to medicine, were indeed in support of it. Rather, "to the contrary, the evidence, scattered and circumstantial as it is, suggests rather that Christians looked to ordinary means of healing medicine and folk or traditional remedies (Paul's advice to Timothy to take a little wine for his stomach [1Tim. 5:23] is an example of the latter)" 71 . This understanding provides current Christians with an important lesson as they debate available vaccines against Covid-19.

Finally, the paper has also emphasized concepts of care for the sick and the dying in the early church. The case of the so-called Cyprian Plague was brought to bear here. While circumstances are definitely different today (that is, while in the early church, health care was individualized, today, it is mainly done in hospitals and other facilities and the fact that Covid-19 is a highly contagious disease), the principle of caring for those affected by disease does not change. As it was demonstrated, this is one area where a stark difference between pagan cults and early Christianity was evident. This is because Christians were governed by the virtue of agape (sacrificial) love as well as their theology of the imago Dei. The paper argues the these should be the guiding principles as modern-day Christians respond to the ravages of Covid-19.

\title{
Care for the Sick in Early Christianity: Lessons for the Current Covid-19 Stricken Church
}

(summary)

\begin{abstract}
Debates on whether early Christians relied solely on exorcism and other miraculous healing under the assumption that all diseases are a result of demonic activity, continue. On the one end of this scholarly continuum are those who hold that early Christians only approached disease and healing as purely spiritual phenomena (hence, focusing on exorcism and other kinds of miraculous healing), while, on the other end, others have argued that early Christians accepted a naturalistic view of the causes for diseases and, consequently, sought naturalistic solutions to diseases. However, like in many other areas of life and thought in early Christianity, there is truth in both of these contentions. Rather than choose sides in this debate, this paper will argue that, just like in other areas, early Christians chose and modified existing approaches to sickness and death based on their understanding of the scriptural teachings on these subjects. As such, their approaches provide some key lessons to the current Covid-19 stricken church.
\end{abstract}

${ }^{71}$ Amundse - Ferngren, The Early Christian Tradition, p. 140. 
Keywords: Covid-19; sickness; Hippolytus; medicine; therapeutics; care; Tertullian; Cyprian Plague; Epidemic; pandemic; magic; healing; exorcism

\section{Bibliography}

\section{Sources}

Arnobius, Adversus nationes, in: The Case against the Pagans: Newly Translated and Annotated, v. 1-2, tr. G.E. McCracken, Ancient Christian Writers, Westminster 1949.

Cyprianus, De mortalitate, in: The Writings of Cyptian, Bishop of Carthage, v. 8, ed. R.E. Wallis, Ante-Nicene Fathers, Buffalo 1886.

Eusebius, Historia ecclesiastica, in: Ecclesiastical History, v. 14, ed. A.C. McGiffert, Nicene and Post-Nicene Fathers Second Series, Buffalo 1890.

Hippocrates, Corpus Hippocraticum, in: Hippocratic Writings, ed. G.E.R. Lloyd, New York 1978.

Hippolytus, Traditio Apostolica, in: The Apostolic Tradition of Hippolytus, tr. B.S. Easton, New York 1934.

Plato, Dialogo de Critica, in: Plato, The Dialogues of Plato: Selections from Charmides, Lysis, Other Dialogues and the Laws, v. 4, tr. B. Jowett, New York 1914.

Tertulianus, De corona, in: Tertullian, Ante-Nicene Fathers: Latin Christianity: Its Founder, Tertullian, v. 3, ed. P. Schaff - A. Menzies, Christian Classics Ethereal Library, Grand Rapids 1885.

\section{Literature}

Amundsen D.W. - Ferngren G.B., The Early Christian Tradition, in: Caring and Curing: Health and Medicine in the Western Religious Traditions, ed. R.L. Numbers - D.W. Amundsen, New York 1986, p. 40-64.

Baldovin J.F., Hippolytus and the Apostolic Tradition: Recent Research and Commentary, "Theological Studies" 64 (2003) p. 520-542.

Barrett-Lennard R., The Canons of Hippolytus and Christian Concern with Illness, Health, and Healing, "Journal of Early Christian Studies" 13/2 (2005) p. 137-164.

Bradshaw P., Redating the Apostolic Tradition: Some Preliminary Steps, in: Rule of Prayer, Rule of Faith: Essays in Honour of Aidan Kavanagh, O.S.B, ed. A. Kavanagh - N. Mitchell - J.F. Baldovin, Collegeville 1996, p. 3-17.

Bradshaw P.F. - Maxwell E.J. - Phillips L.E., The Apostolic Tradition: A Commentary, ed. H.W. Attridge, Minneapolis 2002.

Brent A., Hippolytus and the Roman Church in the Third Century: Communities in Tension before the Emergence of a Monarchical Bishop, Supplements to Vigiliae Christianae 31, Leiden 1995. 
Case S.J., The Art of Healing in Early Christian Times, "The Journal of Religion" 3/3 (1923) p. 238-255.

Casella B.P., Covid Vaccine Helps Us Get Back to Normal, "Optometry Times" 13 (2021) p. 6.

Crouch H.E., History of Basal Cell Carcinoma and Its Treatment, "Journal of the Royal Society of Medicine" 76 (1983) p. 302-306.

Daley B.E., Hope of the Early Church: A Handbook of Patristic Eschatology, Cambridge 1991.

Ferngren G.B., Medicine and Health Care in Early Christianity, Baltimore 2009.

Finn T.M., Ritual Process and the Survival of Early Christianity: A Study of the Apostolic Tradition of Hippolytus, "Journal of Ritual Studies" 3/1 (1989) p. 69-89.

Gilger P., "Litany for a Pandemic: What a Jesuit Learned under Quarantine in Milan", America 222/10 (2020) p. 18-25.

Harnack A., The Mission and Expansion of Christianity in the First Three Centuries, v. 1, tr. J. Moffat, New York 1905.

Harper K., Pandemics and Passages to Late Antiquity: Rethinking the Plague of c. 249 70 Described by Cyprian, "Journal of Roman Archeology" 28 (2015) p. 223-260.

Holman S.R., The Hungry are Dying: Beggars and Bishops in Roman Cappadocia, Oxford Studies in Historical Theology, Oxford 2001.

Horstmanshoff H.F.J., "Galen and His Patients", in: Ancient Medicine in Its Socio-Cultural Context: Papers Read at the Congress Held at Leiden University 13-15 April 1992, ed. Ph.J. van der Eijk. - H.F.J. Horstmanshoff - P.H. Schrijvers, Amsterdam 1995, p. 83-99.

McNary-Zak B. - Nada C. - Lawrence M. - Richard U.S., Useful Servanthood: A Study of Spiritual Formation in the Writings of Abba Ammonas, Cistercian Studies, Trappist 2010.

Montalto S.A., The Covid 19 Vaccine: Fear It Not!, "Malta Medical Journal" 32/3 (2020) p. 1-3.

Mutie J., Death in Second-Century Christian Thought: The Meaning of Death in Earliest Christianity, Eugene 2015.

Mutie J., Attitudes toward Death in Greco-Roman and Early Christian Cultures, "Pakistan Journal of Historical Studies" 2/2 (2017) p. 89-115.

Rebillard É., The Care for the Dead in Late Antiquity, v. 59. tr. E.T. Rawlings - J. Routier-Pucci, Cornell Studies in Classical Philology, Ithaca 2010.

Sarris P., The Justinianic Plague: Origins and Effects, "Continuity and Change" 17/2 (2002) p. 169-182.

Stark R., The Rise of Christianity: A Sociologist Reconsiders History, Princeton 1996.

Stewart-Sykes A., On the Apostolic Tradition: An English Version with Introduction and Commentary, Crestwood 2001.

Temple of the Holy Spirit: Sickness and Death of the Christian in the Liturgy: The Twenty-First Liturgical Conference Saint-Serge, tr. M.J. O’Connell, New York 1983. 
The Canons of Hippolytus, ed. P. Bradshaw, tr. C. Bebawi, Liturgical Studies 2, Nottingham 1987.

Thomas J.C., The Devil, Disease, and Deliverance: Origins of Illness in New Testament Thought, Sheffield 1998.

Tauffragen and Bekenntnis: Studien Zur Sogenannten 'Traditio Apostolica'Zu Den 'Interrogationes De Fide' and Zum 'Romischen Glaubensbekenntnis', ed. W. Kinzig - C. Markschies - M. Vinzent, Arbeiten Zur Kirchengeschichte 74, Berlin 1999, p. 83-99.

Vinzent M., Writing the History of Early Christianity: From Reception to Retrospection, Cambridge 2019.

Wolterstorff N., Tertullian's Enduring Question, in: Inquiring About God, v. 1, ed T. Cuneo, Cambridge 2010, p. 283-303. 